\title{
Działalność w sieci franchisingowej a rozwój przedsiębiorczości w dobie globalizacji
}

Milena Keskin*

\section{Wstęp}

Przedsiębiorczość, aktywizacja zawodowa i rozwój własnej działalności są niezwykle aktualnymi tematami w dzisiejszej ekonomii. Jak się okazuje, nie tylko międzynarodowe korporacje, ale i mali, lokalni przedsiębiorcy mają ogromny wpływ na rozwój globalnej gospodarki. W dobie globalizacji rynek lokalny stał się rynkiem globalnym, a dzięki postępowi technologicznemu, internetowi i ułatwionej współpracy międzynarodowej doszło to internacjonalizacji działań przedsiębiorczych.

Proces globalizacji ekonomicznej, czyli integracja i przeniesienie produkcji poza granice państw, skutkuje wzrostem liczby międzynarodowych przedsiębiorstw oraz ich rozwojem. W ostatnich latach proces ten nabrał ogromnego tempa, ale jego siła zależy od lokalizacji i dziedziny przemysłu. Niepodważalny jest jednak fakt, że globalizacja doprowadziła do długotrwałych i nieodwracalnych zmian w ekonomii międzynarodowej.

Termin „globalizacja” stał się niezwykle popularny na początku lat 90 . XX w., a kojarzy się głównie ze wzrostem integracji i wzajemną zależnością gospodarki światowej (Di Mauro i Dees 2009). Globalizacja w dziedzinie ekonomii pozwala na integrację produktów finalnych i pośrednich oraz rynków pomiędzy państwami, a proces ten idzie w parze ze wzrostem liczby międzynarodowych transakcji ekonomicznych (Prakash i Hart 2000). Dzięki temu dla większości przedsiębiorstw rynkiem docelowym stał się rynek światowy, a handel międzynarodowy zyskał na znaczeniu (Mróz-Gorgoń 2012). Globalizacja ekonomiczna to postępujacy proces integrowania się krajowych i regionalnych rynków w jeden globalny rynek towarów, ustug i kapitału. Proces ten prowadzi do rosnacego prze-

\footnotetext{
* Milena Keskin - magister, Uniwersytet Łódzki, Wydział Ekonomiczno-Socjologiczny, Katedra Ekonomii Przemysłu i Rynku Kapitałowego, milena.keskin.franchising@gmail.com.
} 
nikania się i scalania się rynków oraz umiędzynarodowienia produkcji, dystrybucji, marketingu i przyjęcia przez firmy globalnych strategii dziatania (Liberska 2002, s. 17-18). Umiędzynarodowienie gospodarki światowej pociąga za sobą konieczność ujednolicenia wielu działań wewnątrz przedsiębiorstw działających w tym zakresie, a krajowe przedsiębiorstwa nieuczestniczące w integracji ryzykują izolację gospodarczą i często odnotowują gorsze wyniki finansowe (Lewandowska 2001, s. 5).

Globalizacja może przyczyniać się do powstawania przedsiębiorstw, w szczególności międzynarodowych sieci, do których należy większość sieci franchisingowych (Mróz-Gorgoń 2012). Wraz z postępem procesu globalizacji franchising zyskał miano jednej z najpopularniejszych form rozwoju przedsiębiorstwa. Jego istotą jest możliwość prowadzenia własnej działalności pod znaną i sprawdzoną marką, korzystając z wiedzy i doświadczenia firmy dawcy idei, inaczej franchisingodawcy.

Ogromnym wyzwaniem dla potencjalnych przedsiębiorców jest zdobycie funduszy na otworzenie lub rozwój własnej działalności. Coraz trudniej jest też znaleźć nowatorski pomysł i wejść na nowy rynek, dlatego decydują się oni na działalność na zasadzie franchisingu, która pozwala skorzystać ze sprawdzonej i rozpowszechnionej idei. Ułatwia im to dostęp do kapitału finansowego (np. wsparcie ze strony sieci przy uzyskaniu kredytu bankowego), umiejętności i doświadczenia menedżerskiego czy informacji o lokalnym rynku (Gonzales-Diaz i Solis-Rodriguez 2012, s. 1-2).

Przeprowadzono wiele dyskusji na temat powiązań postaw przedsiębiorczych z rozwojem przedsiębiorstw (głównie małych i średnich) czy start-upów technologicznych. Niewiele jednak pisze się o zależnościach między przedsiębiorczością a rozwojem przedsiębiorstw w sieciach franchisingowych (Dada i Watson 2013, s. 790-812). Celem artykułu jest przedstawienie formy współpracy na zasadzie franchisingu jako przykładu postawy przedsiębiorczej. Artykuł prezentuje także udokumentowane tendencje wzrostu liczby sieci franchisingowych i liczby jednostek franchisingowych w wybranych krajach. Zawiera szereg komentarzy i wniosków z obserwacji rozwoju franchisingu na tle procesów globalizacyjnych na świecie i jego wpływu na postawy przedsiębiorcze. Autorka korzysta głównie z literatury przedmiotu i danych wtórnych oraz z wiedzy zdobytej podczas prowadzenia badań do pracy doktorskiej na temat franchisingu.

\section{Przedsiębiorczość}

W literaturze brakuje jednej powszechnie akceptowanej definicji przedsiębiorczości. Do jej podstawowych cech zalicza się gotowość do założenia i prowadzenia własnej firmy. Ma to ogromne znaczenie w dzisiejszym zglobalizowanym świecie, bowiem z jednej strony jednostka kreuje własne miejsce pracy, dzięki 
czemu chroni się przed bezrobociem i stwarza szansę samorealizacji. W odniesieniu do całej gospodarki wysoki stopień przedsiębiorczości obywateli zmniejsza bezrobocie (Turska 2014).

Klasyczne definicje przedstawiają przedsiębiorczość jako proces planowania, organizowania i prowadzenia działalności gospodarczej oraz podejmowania związanego z nią ryzyka (Griffin 2009). Część definicji oddaje wąskie znaczenie przedsiębiorczości i odnosi się wyłącznie do osób, które otworzyły własną działalność (Schoon i Duckworth 2012), inne zaś, jak ta stworzona przez Schumpetera, prezentują o wiele szerszą perspektywę i definiują przedsiębiorczość jako podejmowanie i realizowanie nowych, innowacyjnych przedsięwzięć, co niekoniecznie ma związek z posiadaniem i prowadzeniem własnego przedsiębiorstwa, ale może przejawiać się zarządzaniem inną firmą lub organizacją (Kaufmann i Dant 1998, s. 7; Lewandowska 2014, s. 163-164; Cosma i Galceava 2014, s. 446).

Także Sudoł zauważa złożoność definicji przedsiębiorczości i sugeruje, by patrzeć na to zjawisko $\mathrm{z}$ wielu perspektyw: psychologii człowieka, aktualnej sytuacji w organizacjach czy mechanizmów gospodarczych i społecznych w państwie lub grupie państw. Podkreśla też, że rozwój przedsiębiorczości zależy od uwarunkowań kulturowych (Sudoł 2008, s. 9-26). (W dalszej części artykułu czytelnik zapozna się szczegółowo z tematyką franchisingu i jego związkiem z rozwojem przedsiębiorczości oraz tematyką uwarunkowań mających wpływ na jego rozwój).

Jak pisze Leoński, przedsiębiorczość najczęściej definiuje się jako zdolność i gotowość do podejmowania i rozwiązywania nowych problemów, umiejętność wykorzystywania szans i zagrożeń oraz dopasowywania się do zmieniających się warunków. Inne definicje przedstawiają przedsiębiorczość jako zdolność do wykonywania jakiejś czynności, np. pracy (ujęcie szersze), lub też jako zespół cech psychicznych tworzących dobrego przedsiębiorcę (ujęcie węższe) (Leoński 2013). Łatwo zauważyć, że definicje te się uzupełniają. Warto wspomnieć o toczącej się między uczonymi dyskusji o tym, czy działalność na zasadzie franchisingu można uznać za postawę przedsiębiorczą. Grupa uczonych biorąca pod uwagę definicje przedsiębiorczości, które koncentrują się na innowacyjności i skłonności do podejmowania ryzyka, jest przeciwna powiązaniu tych dwóch zjawisk. Ponadto kładzie ona nacisk na fakt, że franchising, mimo oferowania przedsiębiorcom dostępu do różnorodnych rynków, stawia przede wszystkim na standaryzację. $Z$ drugiej strony, podążając za definicją Schumpetera, która bierze pod uwagę również możliwość prowadzenia działalności pod czyimś logo, a tą zasadą kieruje się franchising, autorka niniejszego artykułu zgadza się z grupą uczonych (m.in. Adamczyk 1995, s. 14, Dada i Watson 2013) uważających działalność na zasadzie franczyzy² za przejaw przedsiębiorczości.

\footnotetext{
${ }^{2} \mathrm{~W}$ polskiej literaturze przedmiotu pojęcia franchising i franczyza oraz odpowiednio franchisingodawca (-biorca) i franczyzodawca (-biorca) używane są naprzemiennie.
} 
Adamczyk przedstawia następujący pięcioetapowy model procesu przedsiębiorczości:

1) pomysł innowacyjny,

2) motywacja,

3) środki realizacyjne,

4) realizacja,

5) efekt rynkowy.

Wliczając kilka etapów pośrednich, można powiedzieć, że odzwierciedla to także model funkcjonowania franchisingu. Również Dada i Watson w badaniu na temat relacji między postawą przedsiębiorczą a działalnością na zasadzie franczyzy dowodzą, że istnieje istotna zależność między tymi zmiennymi (Dada i Watson 2013, s. 806).

Każde przedsięwzięcie wymaga czasu, dlatego niezwykle ważne są upór i wytrwałość, a w drodze do sukcesu przedsiębiorcy często przeżywają porażki. Nie bez przyczyny o ludziach przedsiębiorczych mówi się: wpychają się oknem, gdy wyrzucono ich drzwiami (Morawski 2014c, s. 8). Przedsiębiorczy Polacy jako główny powód podjęcia decyzji o własnej działalności podają chęć działania i ciągłego rozwoju, które nie zawsze są możliwe w przypadku pracy u kogoś. Znaczenia nabiera zatem motto: „nie ma sensu wspinać się po drabinie, jeśli jest ona przystawiona do niewłaściwej ściany" (Morawski 2014b, s. 15).

Kim jest przedsiębiorca? W psychologii biznesu przedsiębiorcami określa się ludzi, którzy czują się naturalnie i swobodnie w konkurencyjnym środowisku pełnym zmienności i wyzwań. Jednocześnie chętnie podejmują ryzyko i męczą się, pracując na stanowiskach i będąc zależnym od kogoś. Mówi się zatem, że ludzie decydujący się na własną działalność nie powinni się wahać ani wykazywać skłonności do patrzenia wstecz (Morawski 2014a, s. 10-11).

\section{Działalność przedsiębiorcza na zasadzie franchisingu}

W dzisiejszych czasach obecność na globalnych rynkach jest głównym wyznacznikiem sukcesu przedsięwzięcia. Dzięki procesowi globalizacji przedsiębiorstwa zdobyły nowe możliwości rozwoju i przewagi konkurencyjnej. Z drugiej strony muszą połączyć politykę globalną ze znajomością lokalnego rynku i zachowań konsumenta. Wiodącą rolę odgrywają tu przedsiębiorstwa franchisingowe - jako przykład organizacji działających globalnie, w których decyzje podejmowane są w jednym centralnym ośrodku.

Europejski Kodeks Franczyzy definiuje franchising jako system sprzedaży towarów, ustug lub technologii oparty na ścisłej i ciagłej wspótpracy między prawnie i finansowo niezależnymi przedsiębiorstwami, franczyzodawca a indywidualnymi franczyzobiorcami, przy czym franczyzodawca daje biorcy prawo i nakłada na niego obowiąek prowadzenia działalności zgodnie z jego koncepcja (www.eff-franchise.com z dn. 24.02.2017). Bardziej wnikliwą definicję 
franchisingu przytacza Kolarski: franchising jest to metoda prowadzenia dziatalności gospodarczej w zakresie dystrybucji towarów i ustug polegająca na tym, że przedsiębiorstwo otrzymuje prawo do oferowania $i$ sprzedaży określonych towarów $i$ ustug $w$ ramach systemu marketingowego innego przedsiębiorstwa i z wykorzystaniem nazwy, znaków towarowych i doświadczeń techniczno-organizacycjnych tego przedsiębiorstwa (Kolarski 1992, s. 6).

Strategia franchisingu idealnie realizuje popularne hasło: „myśl globalnie, działaj lokalnie", ponieważ w jej ramach dawca idei - inaczej wizjoner - rozpowszechnia swoją koncepcję na różnych rynkach, współpracując z lokalnymi przedsiębiorcami. $Z$ drugiej strony przedsiębiorca - biorca pomysłu - korzysta $\mathrm{z}$ doświadczenia organizacyjnego $\mathrm{i}$ handlowego dawcy oraz rozpowszechnienia i rozpoznawalności jego marki.

Franchising to sposób „współpracy” między firmą udzielającą licencji a siecią działających samodzielnie franchisingobiorców. Termin „współpraca” jest pojęciem bardzo szerokim, ale obecnie najczęściej używanym w literaturze. Tak naprawdę franchising to rodzaj układu ekonomicznego, odgrywający wiodącą rolę wśród innych form współpracy biznesowej. Zyskał miano jednego z najlepszych rozwiązań dla potencjalnych przedsiębiorców pragnących z jednej strony pozostać niezależnymi, a z drugiej nieposiadających wystarczającej wiedzy lub środków finansowych na otworzenie działalności pod własną nazwą (Lewandowska 1999, s. 65-66). Tworzenie własnej marki od podstaw wymaga bowiem czasu i funduszy, a franchising pozwala rozpocząć działalność pod znaną i sprawdzoną nazwą, dzięki czemu przedsiębiorcy nie tracą sił i czasu na popularyzację swojego przedsięwzięcia.

Coraz częściej działalność w sieci franchisingowej jest też dla przedsiębiorców jedyną szansą na rozpoczęcie działalności. Spowodowane jest to kilkoma czynnikami:

1) $Z$ reguły rozpoczęcie działalności w sieci wymaga mniejszego kapitału niż rozwijanie analogicznej działalności samodzielnie. Uważa się, że opłata wstępna wnoszona przez biorcę stanowi małą część kwoty, której wymaga inwestycja w nowe przedsiębiorstwo budowane od podstaw i zdobycie renomy na rynku.

2) Działalność obarczona jest mniejszym ryzykiem niepowodzenia.

3) Franchisingobiorcy otrzymują sprawdzony „przepis na biznes” wraz ze wsparciem organizacyjnym, marketingowym i technicznym ze strony dawcy idei.

Franchising najczęściej wykorzystywany jest jako źródło finansowania dla mniejszych przedsiębiorstw lub przedsiębiorców stawiających pierwsze kroki na rynku. Często, ze względu na ograniczoność środków finansowych, muszą oni podjąć decyzję, czy pozostać przy skromnych zasobach własnych i zachować niezależność (co może być tożsame z zagrożeniem bankructwem lub dekapitalizacją), czy też, rezygnując częściowo z samodzielności, skorzystać z pomocy fi- 
nansowej pozwalającej na dalszy rozwój przedsiębiorstwa. Mimo że istnieje wiele sposobów finansowania przedsiębiorstw (kredyty bankowe, emisja papierów wartościowych, pożyczki), to nie wszystkie z nich są dostępne dla każdego przedsiębiorcy (Lewandowska 2001, s. 13). Znaczącą rolę w możliwości skorzystania z instrumentów rynku kapitałowego odgrywa zarówno wielkość podmiotów, jak i ich forma organizacyjno-prawna, dlatego też przedsiębiorcy coraz częściej korzystają z alternatywnych źródeł finansowania takich jak: venture capital, leasing, forfaiting czy franchising.

Franchising jest również elementem strategii marketingowej, dzięki której franchisingobiorcy wchodzą na nowe rynki, bez konieczności angażowania własnego kapitału. Korzystają oni z efektów skali, bowiem badania marketingowe prowadzone w dużej skali docierają do większej liczby odbiorców niż działania prowadzone jednostkowo. Dzięki badaniom rynku prowadzonym przez dawcę, biorcy uzyskują lepszą wiedzę o lokalnych preferencjach konsumentów.

Umowa franchisingowa podpisywana przez obie strony jest kontraktem cywilnoprawnym pozwalającym na prowadzenie działalności w wyniku przekazania przez uznane na rynku przedsiębiorstwo innej firmie praw do produkcji lub sprzedaży wyrobów według swojej technologii i korzystania ze znaku towarowego za pewną opłatą. Umowy mają najczęściej charakter długoterminowy (nie krócej niż 3-5 lat) lub zawierane są na czas nieokreślony. Związane jest to z przekazaniem własności intelektualnej i przemysłowej, głęboką relacją między dawcą a biorcą systemu, która pierwszemu daje m.in. możliwość rozszerzenia rynku zbytu, a drugiemu rozpoczęcie działalności z ograniczeniem ryzyka (Golawska-Witkowska, Rzeczycka i Mazurek-Krasodomska 2014, s. 27).

Wprawdzie franchisingobiorca pozostaje niezależnym przedsiębiorcą, jednakże akceptując warunki umowy, staje się w pewnym stopniu podległy dawcy systemu. Zdarza się, że franchisingobiorcy narzekają na zbyt silną kontrolę ze strony dawcy, na restrykcje i ograniczanie ich mocy decyzyjnych. Kontroli tego typu wymagają głównie nowe przedsiębiorstwa w sieci lub te będące w początkowej fazie rozwoju, jednak wraz ze wzrostem stabilizacji firmy na lokalnym rynku nadzór ten najczęściej słabnie (Watson 2008, s. 7-8).

Jednym $\mathrm{z}$ filarów franchisingu jest otoczenie biorcy opieką, pomoc w rozwiązywaniu problemów i udzielanie fachowych rad. Najczęściej franchisingodawcy udzielają wsparcia, jeśli chodzi o ubieganie się o kredyt, zakup wyposażenia, znalezienie dogodnej lokalizacji, dobór personelu i decyzje inwestycyjne. Udzielają też opieki prawnej i księgowej czy podczas negocjacji cenowych i lokalowych. Dodatkowo biorca korzysta ze szkoleń, know-how, patentów, licencji i praw autorskich (wszystkie wymienione atrybuty zawarte są w tzw. pakiecie franchisingowym).

Wstąpienie do sieci franchisingowej pozwala niedoświadczonemu przedsiębiorcy poczuć się pewniej w swojej roli, a świadomość, że zawsze może się on zwrócić z prośbą o radę do swojego franchisingodawcy, pozwala skupić się na rozwoju przedsiębiorstwa. 
Oprócz wspomnianych funkcji - w zależności od specyfiki branży, lokalizacji sieci, uwarunkowań geokulturowych, politycznych, ekonomicznych i demograficznych - franchising wspomaga rozwój przedsiębiorczości dzięki swojej funkcji edukacyjnej (pomaga w nabywaniu empirycznej wiedzy biznesowej), zarządzaniu zasobami ludzkimi, funkcji poznawczej (poprzez wchodzenie na nowe rynki, w skali lokalnej i globalnej), funkcji twórczej (daje niezależność, uczy przedsiębiorczości i umiejętności realizacji marzeń), zarządzaniu finansami przedsiębiorstwa oraz funkcjom ogólnomenedżerską i informacyjną. Funkcje franchisingu podsumowuje rysunek 1 (koncepcja własna autorki na podstawie studiów literaturowych).

Rysunek 1. Funkcje franchisingu

\begin{tabular}{|c|c|c|}
\hline 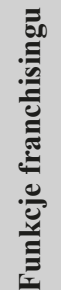 & $\begin{array}{ll}\text { - } & \text { finansowa } \\
\text { - } & \text { marketingowa } \\
\text { - } & \text { zarządcza } \\
\text { - } & \text { opiekuńcza } \\
\text { - } & \text { internacjonalizacyjna } \\
\text { - } & \text { edukacyjna }\end{array}$ & $\begin{array}{ll}\text { - } & \text { poznawcza } \\
\text { - } & \text { twórcza } \\
\text { - } & \text { zarządzania finansami } \\
& \text { przedsiębiorstwa } \\
\text { - } & \text { ogólnomenedżerska } \\
\text { - } & \text { informacyjna itd. }\end{array}$ \\
\hline
\end{tabular}

Źródło: opracowanie własne.

Jednak największą zaletą tego typu współpracy jest możliwość bycia szefem samemu sobie i relatywnie niewielka zależność od franchisingodawcy. Przedsiębiorcy z reguły cieszą się uznaniem społeczeństwa, a sami, dzięki prowadzeniu własnej działalności, mają poczucie spełnienia i komfort psychiczny. Zwykle decydują się na działalność w sieci franchisingowej, ponieważ jest ona - jako sprawdzona recepta na biznes - obarczona mniejszym ryzykiem niepowodzenia. Często przyszłym przedsiębiorcom brakuje odwagi lub funduszy na zaczynanie od zera. Bywa też, że struktura rynku nie pozwala na rozpoczęcie działalności bez znacznych inwestycji w działania marketingowe.

Czasami mylnie uważa się, że działalność w sieci franchisingowej jest 100-procentową gwarancją sukcesu, bowiem dzięki uzyskanemu wsparciu łatwiej można oszacować wielkość sprzedaży i przewidzieć zyski. Trzeba jednak podkreślić, że franchisingobiorcy wprawdzie znajdują się pod ,parasolem ochronnym” dawcy, co redukuje ryzyko prowadzenia działalności, ale nie gwarantuje w 100\% sukcesu.

\section{Własna działalność}

Założenie własnej działalności gospodarczej wymaga zaradności, inwencji i przedsiębiorczości oraz wiąże się z gotowością do podejmowania ryzyka. Wymagane jest posiadanie zasobów kapitału ludzkiego, specjalistycznej wiedzy 
i kompetencji oraz motywacji i wytrwałości w działaniu (Bartnik 2015, s. 11). Głównym powodem decyzji o prowadzeniu własnej działalności jest zwykle chęć wyższych zarobków oraz bycia niezależnym. Jest to też naturalny etap rozwoju, dający poczucie spełnienia, wpływu, umożliwiający spełnienie marzeń, pozwalający na bycie szefem samemu sobie. Samodzielność zwykle daje większą satysfakcję i poczucie kontroli niż jakakolwiek praca na etacie, pobudza też kreatywność i rozwija postawę przedsiębiorczą.

Założenie własnej działalności wiąże się jednak z wieloma trudnościami, a na potencjalnych przedsiębiorców czyha dużo pułapek. Jak pisze Bagiński, 43\% uczestników badań ankietowych przeprowadzonych w 2013 r. przez konsultantów Zielonej Linii (brak danych o liczebności grupy) stwierdziło, że warto jest założyć działalność gospodarczą w Polsce. Odmiennego zdania było ok. 23\% ankietowanych (Bagiński 2014). Zainteresowanie rodaków prowadzeniem własnej działalności wynika głównie z chęci samorealizacji i potrzeby niezależności. $\mathrm{Z}$ drugiej strony wiele osób obawia się podjęcia tak poważnej decyzji. Szczegóły odpowiedzi przedstawiono na wykresie 1. Ponad połowa badanych jako główny powód utrudniający założenie własnej działalności wymieniła brak środków finansowych. Na kolejnych miejscach uplasowały się odpowiednio: trudności biurokratyczne (43\%) i ryzyko bankructwa (42\%). Ważnym czynnikiem, wskazanym przez 32\% ankietowanych, jest także trudność z wybraniem koncepcji biznesowej lub brak pomysłu na nią. Mniej znaczące okazały się: brak wiedzy merytorycznej na temat prowadzenia firmy ( $25 \%$ ) oraz np. wysokie podatki czy potencjalna konkurencja ze Wschodu (brak danych).

Wykres 1. Bariery założenia własnej działalności w Polsce

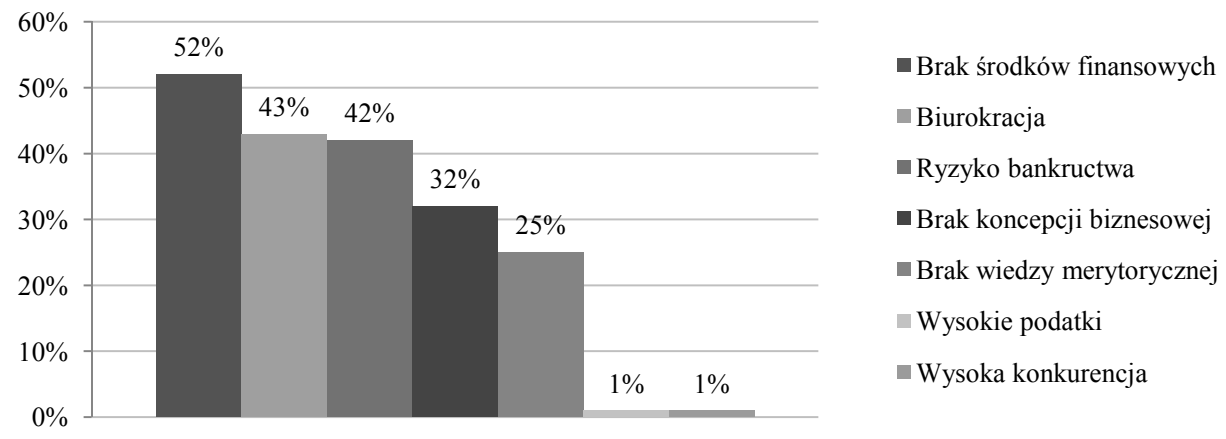

Źródło: opracowanie własne na podstawie Bagiński K. (2014), Własny biznes: chciałbym, ale się boję, „Franczyza\&Biznes”, nr 2(6), s. 9.

Najpopularniejszym źródłem finansowania własnej działalności są fundusze unijne (67\% odpowiedzi) i środki z urzędu pracy (30\%). W dalszej kolejności wymienia się: kredyt (28\%), uczelniane inkubatory przedsiębiorczości $(20 \%)$ oraz 
inne (20\%). Najrzadziej respondenci wskazują inwestorów wspierających rozwój małych biznesów, np. aniołów biznesu (15\%) (Bagiński 2014, s. 9).

Sukces w prowadzeniu własnej działalności zależy jednak od większej liczby czynników. Zalicza się do nich także cechy personalne: zdolność do przewidywania, podejmowania i oceny ryzyka, upór oraz doświadczenie, ale też szczęście. Badania pokazują, że tylko $35 \%$ firm przeżywa pierwsze pięć lat na rynku (Morawski 2014d, s. 7-8). Do czynników zewnętrznych zalicza się także rodzinę - jako jednostkę dającą codzienne wsparcie i motywację. (Morawski 2014b, s. 15).

Przedsiębiorcy zmagają się również z biurokracją i zawiłymi przepisami prawnymi, czasem różnie interpretowanymi przez poszczególne organy skarbowe. Korporacje mają środki na zatrudnienie doradców podatkowych, ale mali przedsiębiorcy zwykle borykają się z tym problemem sami i zwykle z powodu niewiedzy ryzykują łamaniem przepisów (Rolka 2014, s. 84-85). W takich przypadkach działalność w grupie daje wsparcie, a franchisingodawcy chętnie służą radą i pomocą, wspierając w przezwyciężaniu wspomnianych barier.

\section{Uwarunkowania rozwoju działalności franchisingowej w wybranych krajach}

W celu przedstawienia różnorodności czynników wpływających na rozwój franchisingu na potrzeby artykułu wybrano kilka krajów, różniących się znacząco wielkością, populacją czy stopniem rozwoju, w przypadku których dostępne są dane na temat działalności franchisingowej.

Różne warunki wpływają na tempo i sposób rozwoju franchisingu w danym kraju bądź regionie. Zalicza się do nich uwarunkowania np. (koncepcja własna autorki na postawie studiów literaturowych):

1) ekonomiczne,

2) demograficzne,

3) psychologiczne,

4) historyczne,

5) geograficzne

6) i wiele innych.

Można wyróżnić też mniej istotne czynniki, które mają wpływ na wybór sposobu wejścia na dany rynek, np. odległość geograficzna i kulturowa od kraju macierzystego, unikanie odpowiedzialności ze strony kraju przyjmującego, poziom korupcji, poziom rozwoju ekonomicznego czy skuteczność w egzekwowaniu kontraktów.

Franchising - jako niekonwencjonalna forma organizacji współpracy - klasyfikuje się między wertykalnymi formami integracji a zupełnie niepodległymi sposobami współpracy. Sieci franchisingowe stawiające na ekspansję zagraniczną 
muszą odpowiednio wcześnie zauważać oportunistyczne podejście potencjalnych franchisingobiorców. Bezdyskusyjne jest więc międzynarodowe doświadczenie dawców, pozwalające zmniejszyć prawdopodobieństwo wyboru biorców ze złymi praktykami biznesowymi, redukujące koszty kontroli i ogólne ryzyko wejścia na nowy rynek. Decydująca jest zatem wiedza o rynkach międzynarodowych i panujących na nich zwyczajach (Baena 2013, s. 5).

Rozwój działalności franchisingowej przynosi pożytek zarówno krajowi pochodzenia danej firmy, jak i krajowi goszczącemu. W przypadku kraju pochodzenia pozwala pokonać część problemów kulturowych, językowych, technicznych, komercyjnych, prawnych i kadrowych. Kraj przyjmujący zyskuje dzięki wprowadzeniu nowych produktów, usług i technologii oraz dzięki zapewnieniu ciągłego szkolenia dla biorców, treningów, wsparcia ze strony sieci i utrzymywania wysokiej jakości usług całego systemu. Jest to niezwykle ważne dla krajów rozwijających się, bowiem zapoznanie z know-how oraz zapewnienie ciągłości szkoleń i wiedzy technologicznej pomaga budować gospodarkę automatycznie zorientowaną na dostarczanie usług na wysokim poziomie.

W przypadku azjatyckich krajów rozwijających się, np. Wietnamu, międzynarodowym franchisingodawcom zaleca się, by wchodzili na rynek, przejmując lokalne przedsiebiorstwa, dopasowując następnie poziom rozwoju ekonomicznego i standardów do kraju macierzystego, wprowadzając strategię franchisingu na końcu. Robią tak lokalni franchisingodawcy, tzn. rozwijają biznes „od dołu” - dystrybuują produkt, a następnie dostosowują koncepcję do wymogów standaryzacji i jednolitości (Ba Bihn i Terry 2014, s. 211).

Ciekawym przykładem, pokazującym wpływ uwarunkowań ekonomicznych na rozwój przedsiębiorczości, a co za tym idzie franchisingu, jest Polska. Powrót do gospodarki rynkowej na początku lat 90. przyniósł wprawdzie regres, jednak dzięki przedsiębiorczości Polaków i ich chęci do otwierania własnej działalności szybko dogoniliśmy inne kraje: otwarty rynek oparty na własności prywatnej oraz wzrost prywatnej przedsiębiorczości wpłynęły na wzrost innowacyjności i kreatywności. Kolejnym motywem napędowym było wstąpienie Polski do Unii Europejskiej (Kozłowski i Domański 2010, s. 34).

Podobnym do rynku polskiego, pod względem czasowego zamknięcia gospodarki na bodźce zewnętrzne, jest rynek chiński - dopiero w 2004 r. umożliwiono zagranicznym inwestorom wejście na niego. Długoletnia blokada rynku, a następnie powolne otwieranie się na formę współpracy poprzez franchising sprawiły, że idea ta ma nadal duże szanse rozwoju w Chinach (Wang, Zhu i Terry 2008, s. 169-171).

Uwarunkowania ekonomiczne i demograficzne dotyczą faktu bogacenia się społeczeństw, szczególnie krajów Europy Środkowej (np. Rosja) i Azji (Chiny, Indonezja, Indie) czy Ameryki Południowej (Brazylia), gdzie liczebność klasy średniej oraz jej siła nabywcza rosną, co przekłada się na poprawę warunków do rozwoju franchisingu. Wraz ze wzrostem konsumpcji i zainteresowania globalnymi 
markami rośnie zapotrzebowanie na usługi oszczędzające czas i ułatwiające życie, a to właśnie oferują międzynarodowe sieci franchisingowe (Hoffman i Preble 2004, s. 102).

Uwarunkowania psychologiczne nawiązują do uwarunkowań ekonomicznych i procesu globalizacji, a w rezultacie - do poziomu stopnia przedsiębiorczości (szczególnie wśród młodych ludzi) w danym kraju. Potwierdzeniem tej tezy jest sytuacja w krajach takich jak Polska, Francja czy Chiny (oraz częściowo Stany Zjednoczone). Przykładowo w Stanach Zjednoczonych, kolebce kapitalizmu, społeczeństwo jest ukierunkowane na osiąganie sukcesu - obywateli od najmłodszych lat zachęca się do aktywności, rywalizacji i namawia do postaw przedsiębiorczych. W Chinach przedsiębiorczość i własna działalność są synonimem prestiżu. Panuje tam też przekonanie, że np. działalność w sieci franchisingowej jest gotowym przepisem na sukces. Nie bez powodu niektóre przedsiębiorstwa, werbując potencjalnych franchisingobiorców, korzystały ze sloganów typu: „zostań McDonald's Chin” czy „frabryka produkująca szefów” (Wang, Zhu i Terry 2008, s. 173).

Obserwując polski i francuski rynek franchisingu, można wysunąć wniosek, że przedsiębiorcy obu krajów nie wystraszyli się kryzysu ekonomicznego w latach 2008-2012 i postawili na rozwój własnych działalności, co odzwierciedliło się w rosnącej liczbie sieci i jednostek franchisingowych (odrębnych punktów franchisingowych) w obu krajach. W Polsce liczba systemów (w literaturze przedmiotu pojęcie „sieć franchisingowa” i ,system franchisingowy” często używane są naprzemiennie) wynosiła w latach 2008 i 2012 odpowiednio: 512 i 892 (wzrost o 74\%), a jednostek franchisingowych 28629 i 53746 (wzrost o 87\%), podczas gdy we Francji w latach 2010 i 2012 (brak danych dla roku 2008), było odpowiednio 1477 i 1658 sieci franchisingowych (wzrost o 12\%) oraz 58351 i 65059 jednostek franchisingowych (wzrost o ponad 11\%) (Golawska-Witkowska, Rzeczycka i Mazurek-Krasodomska 2014, s. 80; Własny Biznes, Franchising 2014, 4 (110), s. 26-27; Franchising.pl 2015). Kryterium oceny była liczba przedsiębiorstw działających na zasadzie franchisingu.

Inaczej sytuacja miała się w Hiszpanii, kraju o wiele silniej dotkniętym kryzysem, czego rezultatem była wzmożona emigracja i obniżenie poziomu przedsiębiorczości (strach przed otwieraniem własnej działalności, niepewność jutra, ogólnokrajowy pesymizm).

Kolejne z uwarunkowań rozwoju franchisingu, uwarunkowania historyczne i strukturalne rynku, wyrażają się np. poziomem mocy nabywczej klasy średniej czy udziałem własności (firma, kapitał, dom, kwalifikacje), będącej fundamentem klasy średniej. Przykładowo - w Wielkiej Brytanii gwałtowny rozwój klasy średniej nastąpił wraz z rządami Margaret Thatcher. W Polsce oraz w innych krajach Europy Środkowo-Wschodniej kapitalizm urządzany był „na zamówienie”. Według badań odsetek właścicieli firm w Polsce w latach 1989-1999 wzrósł z 3,5\% do 6,6,\% (przykładowo - w 1999 r. udział przedsiebiorców w ogóle ludzi czynnych 
zawodowo w innych krajach wynosił odpowiednio: w Anglii 8\%, w Stanach Zjednoczonych 9\%, a we Włoszech 22,2\%) (Domański 2002, s. 17).

Poza wspomnianymi uwarunkowaniami na rozwój franchisingu w danych krajach wpływają także: czynniki geograficzne (położenie geograficzne, kraje sąsiadujące, klimat), czynniki kulturowe (poziom wykształcenia, poziom korupcji, stosunek do prowadzenia działalności; np. feudalne podejście do prowadzenia firmy w Chinach) czy normy moralne. Przyczyną trudności w otwieraniu jednostek franchisingowych są też zróżnicowany przestrzenny poziom rozwoju ekonomicznego, różnice socjalne, językowe czy różnorodność dialektów (Baena 2013, s. 9).

\section{Podsumowanie}

Wraz z postępem globalizacji i rozwojem technologicznym rośnie konieczność udziału przedsiębiorstw w międzynarodowych rynkach, które poprzez swoją różnorodność stawiają przed przedsiębiorcami bariery trudne do pokonania w pojedynkę lub bez wiedzy o lokalnym rynku. $Z$ drugiej strony powszechny dostęp do kształcenia, także poza granicami kraju, i możliwość zdobycia międzynarodowego doświadczenia zawodowego sprawiają, że zwiększa się potrzeba samorealizacji społeczeństwa, co prowadzi do wzrostu zainteresowania otworzeniem własnej działalności.

Okazuje się, że franchising jest jedną z najpopularniejszych form rozwoju biznesu pozwalającą na połączenie obu tych warunków. Opieka franchisingodawcy, przekazanie know-how, jego doświadczenie i siła marki dają możliwość prowadzenia sprawdzonej działalności z mniejszym ryzykiem niepowodzenia na krajowej lub międzynarodowej arenie. Daje to możliwość samorozwoju, wzmacnia postawy przedsiębiorcze, kreuje miejsca pracy i aktywizując społeczeństwo, wpływa pozytywnie na rozwój gospodarczy. Z przytoczonych przykładów widać, że niektóre kraje profitują bardziej z rozwoju franczyzy, inne potrzebują jeszcze czasu by dostosować swoją strukturę rynku do tej formy współpracy.

\section{Bibliografia}

Adamczyk W. (1995), Przedsiębiorczość. Próba definicji. Przegląd Organizacji, nr 11.

Alon I., Welsh D.H.B. (2002). Global Franchising in Emerging And Transitioning Economies, International Journal of Business and Economics, 2(1).

Antonowicz A. (2010), Franchising, uwarunkowania i perspektywy rozwoju, Wyd. Novae Res, Gdynia.

Ba Binh N., Terry A. (2014), Meeting the Challenges for Franchising in Developing Countries: The Vietnamese Experience, Journal of Marketing Channels, Routledge Taylor \& Francis Group, 21. 
Baena V. (2013), Insights on International Franchising: Entry Mode Decision, Latin American Business Review, January.

Banachowicz E. (1994), Franchising, czyli klucz do przyszłości, Business Press Ltd., Warszawa.

Bagiński K. (2014), Własny biznes: chciałbym, ale się boję. Franczyza\&Biznes, nr 2(6).

Bartnik K.M. (2015), Zróżnicowanie zasobów kapitału ludzkiego na obszarze województwa warmińsko-mazurskiego, Społeczeństwo i Ekonomia, 2(4), Wydawnictwo Uniwersytetu Ekonomicznego, Wrocław.

Castrogiovanni G.J., Justis R.T. (1998), Franchising configurations and transitions. Journal of Consumer Marketing, Vol. 15 Iss. 2.

Cosma D., Galceava S.A. (2014), Dinamics of the Entrepreneuship Concept. Literature Review, Economic Science, Vol. 23, Iss 1.

Dada O., Watson A. (2013), Entrepreneurial orientation and the franchise system: Organisational antecedents and performance outcomes, European Journal of Marketing, Vol. 47 Iss. 5/6.

Dant R.P., Grünhagen M., Windsperger J. (2011), Franchising Research Frontiers for the Twenty-First Century. Journal of Retailing. Vol. 87 (3).

Di Mauro F., Dees S. (2009), Globalisation, Regionalism and Economic Interdependence, Cambridge University Press, Cambridge.

Domański H. (2002), Polska klasa średnia, Monografie FNP, Wrocław.

European Franchise Federation, www.eff-franchise.com/101/franchising-definition-description.html ( $\mathrm{z}$ dn. 24.02.2017).

Franchising.pl, http://franchising.pl/artykul/9165/raport-o-rynku-franczyzy-2015 ( $\mathrm{z}$ dn. 22.10.2015).

Golawska-Witkowska G., Rzeczycka A., Mazurek-Krasodomska E. (2014), Franchising $w$ ksztaltowaniu działalności gospodarczej $w$ Polsce na tle wybranych krajów świata, Zakład Finansów, Wydział Zarządzania i Ekonomii, Politechnika Gdańska, Gdańsk.

Gonzales-Diaz M., Solis-Rodriguez V. (2012), Why do entrepreneurs use franchising as a financial tool? An agency explanation, Journal of Business Venturing, Vol. 27.

Griffin R.W. (2009), Podstawy zarządzania organizacjami, Wydawnictwo Naukowe PWN, Warszawa.

Hunt S.D., Nevin J. (1975), Tying Agreements in Franchising, Journal of Marketing, Vol. 39, July.

Hunt S.D. (1972), The Socioeconomic Consequences of The Franchise System of Distribution, Journal of Marketing, Vol. 36, July.

Kaufmann P.J., Dant R.P. (1998), Franchising and The Domain of Entrepreneurship Research, Journal of Business Venturing, 14, 5-16.

Kolarski G. (1992), Franchising, przewodnik dla poczatkujacych, Centrum Informacji Menedżera, Warszawa. 
Kozłowski P., Domański H. (2010), Po 20 latach. Polska transformacja z perspektywy ekonomicznej, socjologicznej i prawniczej, Instytut Nauk Prawnych PAN, Warszawa.

Leoński W. (2013), Zewnętrzne bariery rozwoju przedsiębiorczości w Polsce, Prace Naukowe Uniwersytetu Ekonomicznego we Wrocławiu, Wrocław, nr 307.

Lewandowska L. (1999), Niekonwencjonalne formy finansowania przedsiębiorczości, Ośrodek Doradztwa i Doskonalenia Kadr sp. z o.o., Gdańsk.

Lewandowska L. (2001), Rozwój firmy, koncepcje zarządzanie i finansowania, Ośrodek Doradztwa i Doskonalenia Kadr Sp. z o. o., Gdańsk.

Lewandowska L. (2014), Franchising As A Way of Creating Entrepreneurship And Innovation, Comparative Economic Research, Volume 17, Number 3.

Liberska B. (2002), Globalizacja. Mechanizmy $i$ wyzwania. Polskie Wydawnictwo Ekonomiczne, Warszawa.

Lopez Fernandez B., Gonzalez-Busto B., Alvares-Castano Y. (2013), The Dynamics of Growth in Franchising, Journal of Marketing Channels, Routledge Taylor \& Francis Group, Vol. 20.

Lundström A., Halvarsson S. (2006), Entrepreneurship Research: Past Perspectives and Future Prospects. Foundations and Trends in Entrepreneurship. Vol. 2, No. 3.

Malara Z. (2012), Przedsiębiorstwo w globalnej gospodarce, wyzwania wspótczesności, Wydawnictwo Naukowe PWN, Warszawa.

Morawski G. (2014), Narodziny własnej firmy, Własny Biznes. Franchising, nr 8(114), sierpień.

Morawski G. (2014), Czy biznes daje szczęście?, Własny Biznes. Franchising, nr 9(115), wrzesień.

Morawski G. (2014), Jak zarobić pierwszy milion, Własny Biznes. Franchising, nr 10(116) październik.

Morawski G. (2014), Pomysły na bezpieczny biznes, Własny Biznes. Franchising, nr 11(117) listopad.

Mróz-Gorgoń B. (2012), Procesy globalizacji i ich wpływ na zarządzanie marką sieci franczyzowych, Prace Naukowe Uniwersytetu Ekonomicznego we Wroclawiu, Wrocław, nr 267.

Prakash A., Hart J.A. (2000), Responding to Globalization, Routledge Advances in International Political Economy, London.

Rolka M. (2014), Co ogranicza w Polsce rozwój małego biznesu? Franczyza \& Biznes, $\mathrm{nr}$ 1(5).

Rundo A., Ziółkowska M. (2013), Nowoczesne modele wspótpracy przedsiębiorstw, Wyd. CeDeWu Sp. z o. o., Warszawa.

Sanghavi N. (1998), Franchising as a Tool for Small Medium Sized Enterprises (SME) Development in Transitional Economies - The Case of Central European Countries, Management Research News, Vol. 21, No. 11.

Schoon I., Duckworth K. (2012), Who becomes an entrepreneur? Early life experiences as predictors of entrepreneurship, Developmental Psychology, Vol. 48(6), November. 
Stawicka M. K. (2009), Franczyza, droga do sukcesu, Wyd. Helion/Onepress, Warszawa.

Sudoł S. (2008), Przedsiębiorczość - jej pojmowanie, typy i czynniki ją kształtujące, Problemy Zarzadzania, Vol. 6, nr 2 (20).

Turska E. (2014), Kapital kariery ludzi młodych, Wyd. Uniwersytet Śląski, Katowice.

Watson A. (2008), Small Business Growth Through Franchising: A Qualitative Investigation, Journal of Marketing Channels, Vol. 5(1).

Wang Z. J., Zhu M., Terry A. (2008), The Development of Franchising in China, Journal of Marketing Channels, Vol. 15 (2/3).

Własny Biznes, Franchising (2014), Tysiąc pomystów na biznes, nr 4 (110), kwiecien. Ziółkowska M. J. (2010), Franczyza, nowoczesny model rozwoju biznesu, Wyd. CeDeWu Sp. z o. o., Warszawa.

\section{Streszczenie}

Dzisiejsze społeczeństwo charakteryzuje się wysokim stopniem przedsiębiorczości, a rządy propagują postawy przedsiębiorcze i zachęcają obywateli do otwierania własnych działalności. W zglobalizowanym i wysoce konkurencyjnym świecie pojedynczy przedsiębiorca napotyka jednak wiele trudności w otwieraniu i prowadzeniu własnego biznesu. Franchising jest dobrym rozwiązaniem ułatwiającym prowadzenie działalności, co pozytywnie wpływa na rozwój przedsiębiorczości.

Słowa kluczowe: franchising, własny biznes, przedsiębiorczość, rozwój przedsiębiorczości, globalizacja

\section{Summary}

\section{Running a Business in a Franchising Chain as an Example of Entrepreneurship Development in the Era of Globalization}

Today's society shows a high level of entrepreneurship; governments support entrepreneurial attitudes and encourage citizens to run their own businesses. However, in a globalized and highly competitive world, potential entrepreneurs face many difficulties in opening and running their own enterprise. Franchising is a suitable tool which facilitates running a business, which has a positive influence on the development of entrepreneurship.

Keywords: franchising, own business, entrepreneurship, entrepreneurship development, globalization

JEL: L26, M21, M13 